\title{
AN EVALUATION OF VISUAL LANDSCAPE QUALITY OF COASTAL SETTLEMENTS: A CASE STUDY OF COASTAL AREAS IN THE VAN LAKE BASIN (TURKEY)
}

\author{
ASUR, F. \\ Department of Landscape Architecture, Faculty of Architecture-Design \\ Yuzuncu Yul University, Zeve Campus, 65090 Tuşba/Van, Turkey \\ (e-mail:feranekasur@gmail.com; phone: +90-5058867677) \\ (Received $22^{\text {nd }}$ Oct 2018; accepted $7^{\text {th }}$ Jan 2019)
}

\begin{abstract}
During the planning and design stages of visual resource management and landscape utilization, it is necessary to evaluate the visual quality of landscape elements, determining the requirement for their preservation, restoration, enhancement, and concealment. Turkey has the advantage of offering a wide range of visual resources to its visitors, shaped by its climatic and geographical features. The Van Lake Basin located in the Eastern Anatolia Region is of particular significance as it is one of the rare locations offering numerous visual resources to the visitors. Sustainable management of these resources is very important in terms of their contributions to the economic development of the region and its local population. Coastsal areas provide resources with limited landscape elements, that are hard to be reproduced. These elements play a critical role in recreation and tourism sectors. In respect of landscape architecture, coastal areas represent a combination of land and water, providing the visitors with the opportunity to enjoy the beauty of nature. The coastal areas around Van Lake have a high potential for recreation activities due to their richness of landscape resources. This study, therefore, aims to evaluate the landscape quality of Van Lake Basin by conducting a biophysical investigation of its coastal areas, containing considerable amount of landscape elements. The study determines the areas that should be prioritized for preservation or restoration, and reveals the most suitable precautions for their sustainability, taking into account their nature and identity.

Keywords: visual resource, landscape quality, recreation activities, coastal area, Van Lake Basin (Turkey)
\end{abstract}

\section{Introduction}

According to the European Landscape Convention, every country is obliged to identify, plan, preserve, and restore the landscape elements within their borders (Anonymous, 2000). Thus, it is necessary to evaluate the cultural and natural landscape properties of different regions in a country. The determination of human-environment interactions through the method known as "visual impact analysis" offers a solution for the challenge of improving a given environment in terms of its basic social and physical potential, and utilization of modern habitable areas in these areas (Bozhüyük, 2007). The coastal areas have been the most important habitable locations for numerous civilizations during history. The importance attributed to water as a visual landscape element dates back to the gardens of Mesopotamia and Egypt (Burmil et al., 1999). Many studies (Arriaza et al., 2004; Özhanc1 and Y1lmaz, 2011) report that water aesthetically increases the quality of a given landscape.

Cosskun and Kaplan (2001) maintain that visual problems arising from changes in the urban landscapes lead to loss of prestige for the habitat and reduce the natural-cultural value of the location. Consequently, the studies evaluating the impact of such changes on the cultural properties, physical development, and loss of social life become extremely important (Hepcan, 2003). The cities with coastal areas suffer from certain limits due to interventions to the landscape. Generally, shorelines can provide a 
valuable opportunity for recreational activities and tourism sector; the coastal line of the Van Lake and nearby regions are quite rich in this respect.

\section{Review of Literature}

\section{Coastal Landscape}

Coastal areas are landscape resources with limited landscape elements that are hard to reproduce, and they can provide the opportunity to enjoy the beauty of nature to their visitors as they represent the combination of land and water.

The strips of land that lie beside seas, lakes, and rives are called "coastal areas". Coasts are some of the most rapidly evolving geographical formations on the face of the earth (Karabey, 1978; Duru, 2001). Coastal areas and shores are important resources that can meet the ever-increasing recreational needs of urban dwellers. While deciding on the physical planning of shorelines, it is important to balance the needs of the society with the natural potential, and to underline the identity and culture of the shoreline while preserving the integration of the settlement (Clark, 1996; Duru, 2001; Kaya, 2006; Gülez et al., 2007; Yazici, 2018). The populations of the coastal regions keep increasing all around the world. As a result of this phenomenon, the utilization of the landscape elements for recreational and tourism demands has been rising. Resultantly, coastal areas suffer from environmental problems that are very difficult -and sometimes outright impossible- to fix (Y1lmaz, 2006).

The interest of humans on water resources have not been limited to seas, but have also been directed towards lakes and rivers. Activities like swimming, fishing, birdwatching, kayaking, sailing, windsurfing, and canoeing are conducted not only on seas but on the lakes as well (Soykan, 2000). Van Lake is the largest lake in Turkey, the largest alkaline lake in the world, and represents one of the most significant visual landscape resources of the region. As the lake is located over the migration routes of birds, it also provides for an ornithological and recreational potential as an ecosystem.

\section{Visual Landscape Quality}

Evaluation of a visual landscape is an inquiry for the location with the aesthetical criteria and elements determined beforehand in mind (Parsons and Danial, 2000; Palmer, 2003). In that regard, a visual landscape consists of a series of interactions between abiotic, biotic, visual, and cultural elements (Kane, 1981; Bulut and Y1lmaz, 2007; Gruehn and Roth, 2008; Yazici, 2018). Visual landscape evaluation is a method utilized while comparing the aesthetical values of study areas, determining priorities during preservation efforts, and identifying the changes in the landscape character. During the planning and design stages of visual resource management and landscape utilization, it is necessary to evaluate the quality of visual landscape elements of the study area to prioritize their preservation, restoration, enhancement, and concealment (Kane, 1981; Palmer and Hoffman, 2001).

There are three approaches used in the determination of the visual quality of a given piece of landscape. These are the physical (topographical aesthetics), psychological, and psychophysical approaches (Daniel and Boster, 1976; Lothian, 1999; Daniel, 2001; Kaptanoğlu, 2006; Çakc1, 2007). In the perception-based evaluation method, a group of observers are asked to quantify the quality of the landscape they are observing or seeing through pictures (Daniel, 2001). Making use of photographs is a valid approach when 
determining the visual status of a landscape (Hall, 2001; Clay and Smidt, 2004; Çakc1, 2007; Dupont et al., 2017; Palmer, 2019).

As the visual quality of the landscape is naturally an extension and result of its physical properties, the evaluation in this method is based on the objective or physical approaches. According to Palmer (2019), bio-physical influences of a landscape should always be considered in the evaluations. The morphological-aesthetic approach where the landscape qualities and elements that are believed to have influence over the beauty of the sight -and have been analyzed in terms of their contents- shall be conducted by experts only. Since the evaluations of a single expert might be questionable, it is reasonable to conduct evaluations with at least five experts (Wherrett, 1996; Çakc1, 2007; SNH, 2013; Palmer, 2019). According to literature (BCMF, 1997; Clay and Daniel, 2000; Wu et al., 2006; Arriaza et al., 2004; Sevenant and Antrop, 2009; Uzun and Müderrisoğlu, 2011; Jahany et al., 2012; SNH, 2013; Huang, 2014; BLM, 2016) the biophysical parameters are the angle of visibility, the configuration and silhouette of visible borders, the silhouette of the land, the expanse, inclination, impression, land formations, surface relief, land cover, neighboring vistas, cultural properties, vegetation, richness in terms of species, and the presence of water.

Various studies have been conducted on the evaluation of visual qualities of landscapes. Smardon (1979) have counted color, texture, line, shape, and proportion properties with influence levels of low, medium, high, and irrelevant; and further quantized each element and created a numerical system. He grouped landscape elements as vegetation, water surface, and structure, and evaluated them numerically.

Ayad (2005) has researched the potential of GIS and distant perception methods in a coastal region in Egypt. He transferred the landscape properties of the study area into a GIS environment with numerical values and determined the utilization of land, distance to coast strip, cover, and topographical variations in the digital environment.

Huang (2014) has analyzed the landscape elements of Washtenaw County, Michigan, and evaluated the visual quality. In his study, Huang presented the participants with 50 photographs of various vistas from the study area, and asked them to sort the locations out based on their preferences and intuitions. He also conducted map-making analyses and visual quality evaluations. He found out that participants were inclined towards the vistas with natural properties.

Naspetti et al. (2016) used a selection of landscape images containing photovoltaic elements and conducted a Q-sort study. 34 participants, some of which were landscape and lighting experts, were presented with 54 landscape images. They were asked to sort them in three different categories to determine the best way of integrating photovoltaic systems into the urban and rural landscapes.

Keleş et al (2018) studied Edirne / Turkey, representing one of the most interesting cities of the region in terms of tangible and intangible cultural landscape elements. They presented a questionnaire and photographs of the landscape elements to a group of experts and asked them to evaluate the structures, textures, and characters. The results of the study were used in rational planning and preservation of the cultural resources by various authorities.

The Van Lake Basin, rich in physical geographical formations, contains various types of geomorphic elements. It also contains ancient settlements developed by numerous civilizations in its long history. Thus, the area contains various population and settlement types that are quite different from each other. As it is a closed basin, the area contains idiosyncratic elements and properties each of which should be inspected 
from different perspectives. This is a novel study since the evaluation of visual landscape qualities of settlements in the coastal lines of the Van Lake has never been carried out before. In the present study, significant settlement areas in the coastal lines of the cities of Van and Bitlis are inspected in terms of their visual landscape qualities using Q-Sort analysis. Q- sort analysis is a relatively new tool not only as approach but particularly following the quite recent rediscovery of its usefulness in those fields where psychometric knowledge of individuals have thorough implications (Kramer et al., 2003). Various biophysical parameters (general interest, naturalness, the presence of water, vegetation, topographic variation, natural and cultural elements, and color variety) are also investigated. The aim of the study is to present a reference point for future studies and efforts to remove the negative impact of various factors on the natural and visual landscape elements and to act as a guide for visual resource management, decision making/strategy, and restoration studies.

\section{Materials and Methods}

\section{Material}

The coastal strips of significant settlements on the shorelines of Van Lake Basin form the material of the study (Figure 1). These settlements belong to district of Erciş, Adilcevaz, Ahlat, Tatvan, Gevaş and Edremit, the most significant district in the region.

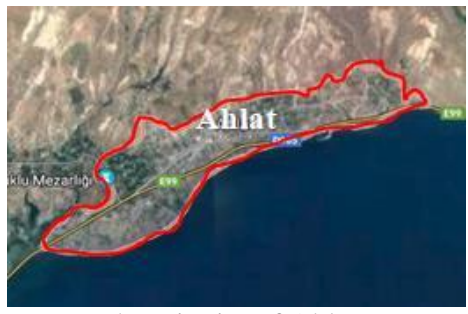

The District of Ahlat

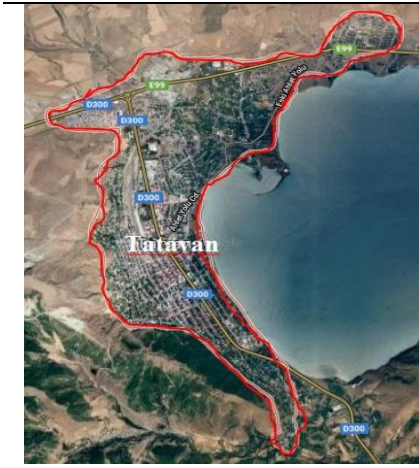

The District of Tatvan

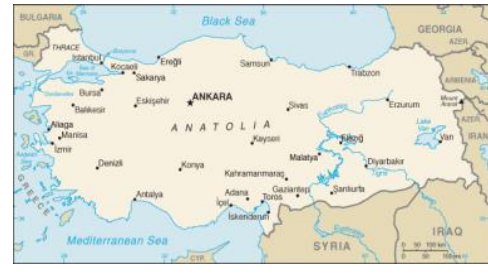

Turkey

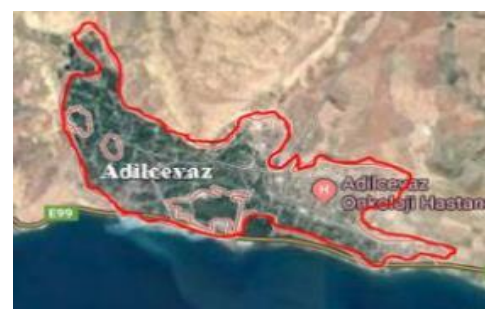

The District of Adilcevaz
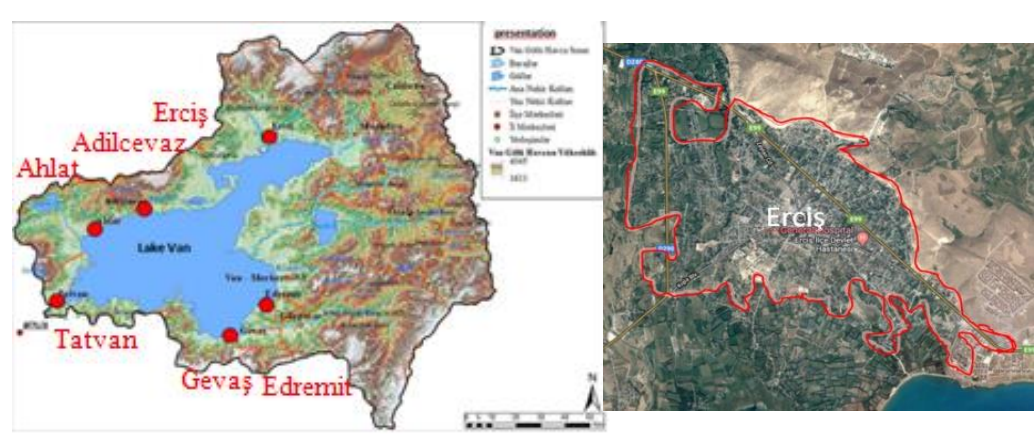

Van Lake Basin

The District of Erciş

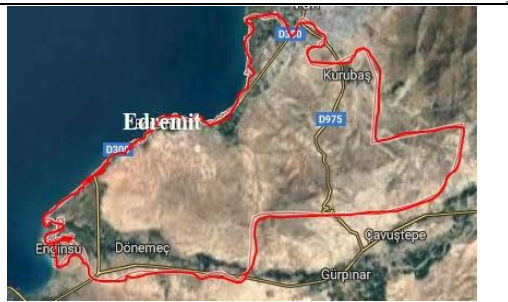

The District of Edremit

Figure 1. Satellite images of settlements on the coastal regions of the Van Lake Basin 
The photographs of the coastal locations were taken between 09.00 and 17.00 in summer months using a digital camera. Areas open to the public were preferred, taking into consideration the active recreational use of the locations by the community. A total of 186 photographs were taken in 6 different coastal locations, 24 of them selected (4 from each location) for the final inquiry. The experts were then asked to specify a preference ratio for each location (Table 1), and each individual picture.

Van Lake is believed to have formed as a result of water gathering inside a crater formed by the explosion of the Nemrut volcanic mountain. The surface area of the lake is $3,713 \mathrm{~km}^{2}$, and the lake contains numerous bays. It represents an aquatic ecosystem, different from both the fresh and saltwater ecosystems. With an elevation of 1646 meters, it is surrounded by volcanic mountain masses to the west and north, mountain ranges with steep slopes to the south, and a relatively lower morphological field towards east and northeast, creating a closed basin. The shores are grainy and pebbly, and contain numerous rocky or cliffy areas, presenting various areas of interest in terms of views and vistas.

The district of Erciş is approximately $100 \mathrm{~km}$ to the Van city center and is built over the Erciş plains. The district has an elevation of 1690 meters, influenced positively by the well-watered terrain, large number of streams and watercourses, and its coastal position. The area has numerous natural catchment areas. Many landscape design studies were conducted on the shorelines by municipalities in 2017 to provide recreational opportunities for the public (Anonymous, 2018a).

The district of Adilcevaz is positioned inside a valley surrounded by the skirts of the Süphan Mountain, positioned $71 \mathrm{~km}$ distance to the city center of Bitlis towards the northwest of the lake with an elevation of 1690 meters. Most of the district lacks a soil ground cover; thus, it is weak in vegetation. Local authorities have conducted various coastal landscape studies in order to increase the recreational use of the landscapes (Anonymous, 2018b).

The district of Ahlat is within the borders of Bitlis, with an elevation of 1545 meters, $44 \mathrm{~km}$ north of Tatvan district. The district is built over a plateau between Süphan and Nemrut Mountains and East Anatolia Region. Ahlat is located in the northwest shores of the Van Lake, and the coastal landscapes are actively used by the community, especially during summer (Anonymous, 2018b).

The district of Tatvan is also within the borders of Bitlis, approximately $25 \mathrm{~km}$ to the city center. With an elevation of 1671 meters and its position on a high elevation location towards the southwest of Van Lake, most of the district area is covered with mountains. Tatvan also has a historical importance as it is positioned over the Silk Road (Anonymous, 2018b).

The district of Gevaş is $35 \mathrm{~km}$ distant to the Van city center, built at an elevation of 1750 meters on the shorelines of the Van Lake. The district is quite rich in historical artworks and natural vistas. Gevaş is the favorite location of many tourists and local populations, particularly during the summer. Tatvan is located in the skirts of the Artos Mountain, the highest of the Kavuşahap Mountain range and the extension of the Southeastern Toros Mountains (Anonymous, 2018a).

Finally, the district of Edremit is only $15 \mathrm{~km}$ to the city center of Van within elevation of 1846 meters. With a south-southeastern orientation, the district is quite rich in natural and cultural landscape elements. Edremit has always been popular due to its beautiful shoreline, having a high value in terms of visual landscape (Anonymous, 2018a). 
Table 1. Selected photographs of coastal landscapes, and the preference ratios by experts

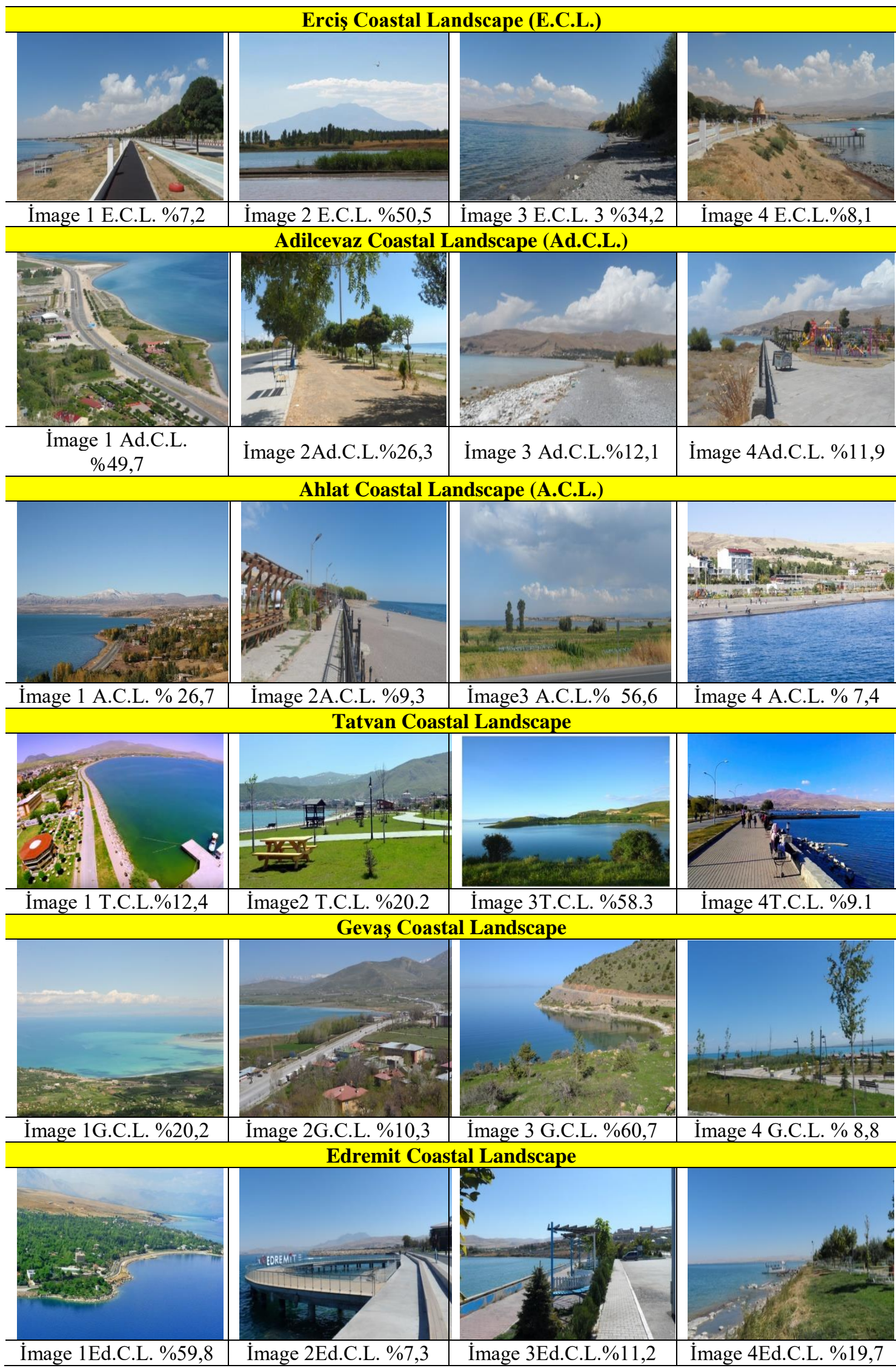


The touristic data regarding the provinces of Bitlis and Van where these settlements are located are as follows: According to Bitlis Province Directorate of Culture and Tourism 2018 data, the native and foreign tourist count that visited touristic facilities of Bitlis in 2017 is 179,639, of which 176,073 were natives and 3,566 were foreigners. According to Van Province Directorate of Culture and Tourism 2018 data, the native and foreign tourist count that visited touristic facilities of Bitlis in 2017 is 1,070.260, of which 584,040 were natives and 486,220 were foreigners.

\section{Method}

The method chosen for the evaluation of the visual landscape quality was a combination of methods in the literature by BCMF (1997), Wu et al. (2006), Çakc1 (2007), Uzun and Müderrisoğlu (2011), Jahany et al. (2012), SNH (2013), BLM (2016), and Huang (2014), developed by Aşur (2017) (Table 2). The main criteria evaluated by the experts by looking at the photographs were their personal opinion of the general view, naturalness, presence (and clarity) of water, vegetation, topographical variation, man-made constructs with a positive contribution, and color variety.

Table 2. The evaluation chart according to visual landscape biophysical parameters that developed by Aşur (2017)

\begin{tabular}{|c|c|c|c|c|c|}
\hline \multirow[b]{2}{*}{$\begin{array}{c}\text { Landscape } \\
\text { qualifications }\end{array}$} & \multicolumn{5}{|c|}{ Points } \\
\hline & $\begin{array}{c}+2(\text { Very beautiful } \\
\text { n1) }\end{array}$ & $+1($ Beautiful n2) & 0(Ordinary n3) & -1(Ugly n4) & -2(Very Ugly n5) \\
\hline General view & $\begin{array}{l}\text { I liked it very } \\
\text { much }\end{array}$ & I like & normal & I do not like & I did not like at all \\
\hline $\begin{array}{c}\text { Degree of } \\
\text { naturalness }\end{array}$ & $\begin{array}{c}\begin{array}{c}\text { Natural elements } \\
\text { are very dominant }\end{array} \\
\end{array}$ & $\begin{array}{c}\text { Natural elements } \\
\text { less dominant }\end{array}$ & \begin{tabular}{|c|}
$\begin{array}{c}\text { Natural elements } \\
\text { half dominant }\end{array}$ \\
\end{tabular} & \begin{tabular}{|l|} 
Natural elements \\
are not dominant
\end{tabular} & $\begin{array}{c}\text { Non-natural } \\
\text { elements dominant }\end{array}$ \\
\hline $\begin{array}{l}\text { Vegetation } \\
\text { presence }\end{array}$ & $\% 80-100$ & $\% 60-80$ & $\% 40-60$ & $\% 20-40$ & $\% 0-20$ \\
\hline Water view & $\begin{array}{l}\text { Very dominant } \\
\text { and clear water } \\
\text { surface }\end{array}$ & $\begin{array}{l}\text { Water surface is } \\
\text { very visible but } \\
\text { non-clear water }\end{array}$ & $\begin{array}{c}\text { Water surface } \\
\text { obvious }\end{array}$ & $\begin{array}{l}\text { Water surface is } \\
\text { obvious and dirty }\end{array}$ & $\begin{array}{c}\text { appearance of the } \\
\text { water is very bad, } \\
\text { dirty }\end{array}$ \\
\hline $\begin{array}{l}\text { Topographic } \\
\text { diversity }\end{array}$ & Very clear & Clear & Little clear & Not clear & Not at all clear \\
\hline $\begin{array}{c}\text { Presence of } \\
\text { human-made } \\
\text { positive elements / } \\
\text { historical } \\
\text { buildings and } \\
\text { typical houses }\end{array}$ & $\% 80-100$ & $\% 60-80$ & $\% 40-60$ & $\% 20-40$ & $\% 0-20$ \\
\hline Variety of colors & $\begin{array}{l}\text { Color variety is } \\
\text { very and } \\
\text { compatible }\end{array}$ & $\begin{array}{l}\text { Color diversity } \\
\text { less and } \\
\text { compatible }\end{array}$ & Color variety less & $\begin{array}{c}\text { Very little variety } \\
\text { of colors }\end{array}$ & $\begin{array}{l}\text { No variety of } \\
\text { colors }\end{array}$ \\
\hline
\end{tabular}

In this study, because of the biophysical evaluation of visual landscape quality, expert opinions were consulted. Biophysical properties of the visual landscapes were quantized numerically (very beautiful as +2 , beautiful as +1 , ordinary as 0 , ugly as -1 , and very ugly as -2). 35 experts, all of whom had previously seen the locations in person, were presented with the 24 photographs from the 6 locations (4 from each location) with an online questionnaire. All the evaluations were recorded. Each of the 4 pictures for a given location was given a preference ratio by the experts. The value of a given piece of the landscape was calculated based on the scores given to them by the experts. A high score indicates a potentially desirable view and a high preference rate 
by the community. The results are listed in Tables 3 to 8 . The Likert-scale scores explained above were then Q-sorted, revealing the meaningfully preferred locations over the others. In order to compute achieved points for each photo, the formula below is used (Kramer et al., 2003; Golchin et al., 2012).

$$
N=\sum_{i=1}^{5} n_{i}(3-i)
$$

$\mathrm{N}=$ Total points for each photo.

$\mathrm{n} 1=$ Number of users which choose very beautiful quality photo.

$\mathrm{n} 2=$ Number of users which choose beautiful quality photo.

$\mathrm{n} 3=$ Number of users which choose normal quality photo.

$\mathrm{n} 4=$ Number of users which choose ugly quality photo.

n5 $=$ Number of users which choose very ugly quality photo.

\section{Results and Discussion}

As can be seen from the results (Tables 3 to 8), the image 2 E.C.L. was the most liked location in the Erciş coast (50.5\% ratio), while the 1 Ad.C.L from the Adilcevaz coast $(49.7 \%)$, the image 3 A.C.L from the Ahlat (56.6\%), the image 3 T.C.L from the Tatvan (58.3\%), image 3 G.C.L from the Gevaş coast (60.7\%), and image 1 Ed.C.L. from the Edremit $(59.8 \%)$ were the ones for every location earning the highest ratios. One common theme detected in these selections was the inclination towards natural beauties of shores, while the artificial landscape elements were mostly avoided. The assessment of study outcomes according to the 7 parameters of visual landscape quality; Q-Sort analysis of the expert opinions revealed that the coastal of the Gevas district was the most preferred one amongst all the locations in terms of the beauty of the general view. Edremit and Tatvan coastal area follow closely.

Table 3. The evaluation results of the Erciş's coastal area

\begin{tabular}{c|ccccccc}
\hline $\begin{array}{c}\text { Landscape } \\
\text { qualifications }\end{array}$ & $\mathbf{+ 2}(\mathbf{n 1})$ & $\mathbf{+ 1}(\mathbf{n} 2)$ & $\mathbf{0}(\mathbf{n 3})$ & $\mathbf{- 2}(\mathbf{n 4})$ & $\mathbf{- 1}(\mathbf{n 5})$ & Photo score N & Standart dev \\
\hline Deg. of nat. & 3 & 10 & 14 & 7 & 1 & $\mathbf{7}$ & 0,96406 \\
\hline Veg. presence & 1 & 12 & 13 & 7 & 2 & $\mathbf{3}$ & 0,95090 \\
\hline Water view & 5 & 13 & 14 & 2 & 1 & $\mathbf{1 9}$ & 0,91853 \\
\hline $\begin{array}{c}\text { Top. div. } \\
\text { P. of hum. m.pos. } \\
\text { elem. }\end{array}$ & 4 & 9 & 16 & 5 & 1 & $\mathbf{1 0}$ & 0,93144 \\
\hline Var. of colors & 4 & 6 & 16 & 9 & 2 & $\mathbf{- 3}$ & 0,95090 \\
\hline
\end{tabular}

Table 4. The evaluation results of the Adilcevaz's coastal area

\begin{tabular}{c|ccccccc}
\hline $\begin{array}{c}\text { Landscape } \\
\text { qualifications }\end{array}$ & $\mathbf{+ 2}(\mathbf{n 1})$ & $\mathbf{+ 1}(\mathbf{n} 2)$ & $\mathbf{0}(\mathbf{n} 3)$ & $\mathbf{- 2}(\mathbf{n 4})$ & $\mathbf{- 1}(\mathbf{n 5})$ & Photo score N & Standart dev \\
\hline Deg. of nat. & 1 & 12 & 13 & 7 & 2 & $\mathbf{3}$ & 0,95090 \\
\hline Veg. presence & 2 & 7 & 15 & 6 & 5 & $\mathbf{- 5}$ & 1,08852 \\
\hline Water view & 4 & 9 & 17 & 4 & 1 & $\mathbf{1 1}$ & 0,98731 \\
\hline Top. div. & 2 & 9 & 16 & 7 & 1 & $\mathbf{4}$ & 0,90005 \\
\hline $\begin{array}{c}\text { P. of hum. m.pos. } \\
\text { elem. }\end{array}$ & 0 & 8 & 18 & 6 & 3 & $\mathbf{- 4}$ & 0,86675 \\
\hline Var. of colors & 2 & 5 & 19 & 6 & 3 & $\mathbf{- 3}$ & 0,95090 \\
\hline
\end{tabular}


Table 5. The evaluation results of the Ahlat's coastal area

\begin{tabular}{c|ccccccc}
\hline $\begin{array}{c}\text { Landscape } \\
\text { qualifications }\end{array}$ & $\mathbf{+ 2}(\mathbf{n 1})$ & $\mathbf{+ 1}(\mathbf{n 2})$ & $\mathbf{0}(\mathbf{n 3})$ & $\mathbf{- 2}(\mathbf{n} 4)$ & $\mathbf{- 1}(\mathbf{n 5})$ & Photo score N & Standart dev \\
\hline Deg. of nat. & 2 & 9 & 16 & 7 & 1 & $\mathbf{4}$ & 0,90005 \\
\hline Veg. presence & 0 & 8 & 18 & 6 & 3 & $\mathbf{- 4}$ & 0,86675 \\
\hline Water view & 4 & 15 & 10 & 5 & 1 & $\mathbf{1 6}$ & 0,98048 \\
\hline Top. div. & 3 & 10 & 14 & 7 & 1 & $\mathbf{7}$ & 0,96406 \\
\hline $\begin{array}{c}\text { P. of hum. } \\
\text { m.pos. elem. }\end{array}$ & 2 & 5 & 18 & 8 & 2 & $\mathbf{- 3}$ & 0,90090 \\
\hline Var. of colors & 3 & 8 & 18 & 5 & 1 & $\mathbf{7}$ & 0,90098 \\
\hline
\end{tabular}

Table 6. The evaluation results of the Tatvan's coastal area

\begin{tabular}{c|ccccccc}
\hline $\begin{array}{c}\text { Landscape } \\
\text { qualifications }\end{array}$ & $\mathbf{+ 2}(\mathbf{n 1})$ & $\mathbf{+ 1}(\mathbf{n} 2)$ & $\mathbf{0}(\mathbf{n 3})$ & $\mathbf{- 2}(\mathbf{n} 4)$ & $\mathbf{- 1}(\mathbf{n 5})$ & Photo score N & Standart dev \\
\hline Deg. of nat. & 4 & 9 & 14 & 7 & 1 & $\mathbf{8}$ & 1,00252 \\
\hline Veg. presence & 3 & 8 & 18 & 5 & 1 & $\mathbf{7}$ & 0,90098 \\
\hline Water view & 9 & 11 & 13 & 1 & 1 & $\mathbf{2 6}$ & 0,90005 \\
\hline Top. div. & 4 & 9 & 17 & 4 & 1 & $\mathbf{1 1}$ & 0,98731 \\
\hline $\begin{array}{c}\text { P. of hum. m.pos. } \\
\text { elem. }\end{array}$ & 2 & 6 & 16 & 9 & 2 & $\mathbf{- 3}$ & 0,95090 \\
\hline Var. of colors & 6 & 10 & 15 & 4 & 0 & $\mathbf{1 8}$ & 0,90563 \\
\hline
\end{tabular}

Table 7. The evaluation results of the Gevaş's coastal area according to visual landscape biophysical parameters

\begin{tabular}{c|ccccccc}
\hline $\begin{array}{c}\text { Landscape } \\
\text { qualifications }\end{array}$ & $\mathbf{+ 2}(\mathbf{n 1})$ & $\mathbf{+ 1}(\mathbf{n} 2)$ & $\mathbf{0}(\mathbf{n 3})$ & $\mathbf{- 2}(\mathbf{n 4})$ & $\mathbf{- 1}(\mathbf{n 5})$ & Photo score N & Standart dev \\
\hline Deg. of nat. & 6 & 10 & 15 & 4 & 0 & $\mathbf{1 8}$ & 0,90563 \\
\hline Veg. presence & 10 & 11 & 11 & 2 & 1 & $\mathbf{2 7}$ & 0,98144 \\
\hline Water view & 11 & 16 & 6 & 2 & 0 & $\mathbf{3 6}$ & 0,85700 \\
\hline Top. div. & 9 & 11 & 12 & 3 & 0 & $\mathbf{2 6}$ & 0,95001 \\
\hline $\begin{array}{c}\text { P. of hum. } \\
\text { m.pos. elem. }\end{array}$ & 4 & 7 & 13 & 7 & 4 & $\mathbf{0}$ & 1,16316 \\
\hline Var. of colors & 6 & 12 & 14 & 2 & 1 & $\mathbf{2 0}$ & 0,94824 \\
\hline
\end{tabular}

Table 8. The evaluation results of the Edremit's coastal area

\begin{tabular}{c|ccccccc}
\hline $\begin{array}{c}\text { Landscape } \\
\text { qualifications }\end{array}$ & $\mathbf{+ 2}(\mathbf{n} 1)$ & $\mathbf{+ 1}(\mathbf{n} 2)$ & $\mathbf{0}(\mathbf{n 3})$ & $\mathbf{- 2}(\mathbf{n 4})$ & $\mathbf{- 1}(\mathbf{n 5})$ & Photo score N & Standart dev \\
\hline Deg. of nat. & 4 & 15 & 10 & 5 & 1 & $\mathbf{1 6}$ & 0,98048 \\
\hline Veg. presence & 6 & 12 & 14 & 2 & 1 & $\mathbf{2 0}$ & 0,94824 \\
\hline Water view & 7 & 17 & 9 & 2 & 0 & $\mathbf{2 9}$ & 0,82197 \\
\hline $\begin{array}{c}\text { Top. div. } \\
\text { P. of hum. m.pos. } \\
\text { elem. }\end{array}$ & 4 & 15 & 10 & 5 & 1 & $\mathbf{1 6}$ & 0,98048 \\
\hline Var. of colors & 10 & 11 & 11 & 3 & 0 & $\mathbf{- 4}$ & 0,86675 \\
\hline
\end{tabular}

As can be observed from Table 9, half of the 6 coastal locations have received higher view scores compared to the other 3 . Adilcevaz shores were given the lowest score.

The standard deviation for the general view property of the expert evaluations of visual landscape value of Erciş, Adilcevaz, Ahlat, Tatvan, Gevaş and Edremit coastal areas are given in Figures 2, 3, and 4. 
Table 9. The results of the evaluation of visual landscape elements in terms of beauty of the general view

\begin{tabular}{ccccccc}
\hline Photo name & $\begin{array}{c}+\mathbf{2}(\text { Very } \\
\text { Beautiful n1 })\end{array}$ & $\begin{array}{c}+\mathbf{1}(\text { Beautiful } \\
\mathbf{n} 2)\end{array}$ & $\begin{array}{c}\mathbf{0} \text { (Ordinary } \\
\mathbf{n 3})\end{array}$ & $\begin{array}{c}\mathbf{- 1 ( U g l y} \\
\mathbf{n 4})\end{array}$ & $\begin{array}{c}\mathbf{- 2 ( V e r y} \text { Ugly } \\
\mathbf{n 5})\end{array}$ & $\begin{array}{c}\text { Photo score } \\
\mathbf{N}\end{array}$ \\
\hline E.C.L. & 4 & 9 & 17 & 4 & 1 & $\mathbf{1 1}$ \\
\hline Ad.C.L. & 4 & 10 & 14 & 6 & 1 & $\mathbf{1 0}$ \\
\hline A.C.L. & 7 & 17 & 9 & 2 & 0 & $\mathbf{2 9}$ \\
\hline T.C.L. & 11 & 15 & 8 & 1 & 0 & $\mathbf{3 6}$ \\
\hline G.C.L. & 17 & 13 & 4 & 0 & 1 & $\mathbf{4 5}$ \\
\hline Ed.C.L. & 12 & 18 & 3 & 1 & 1 & $\mathbf{3 9}$ \\
\hline
\end{tabular}

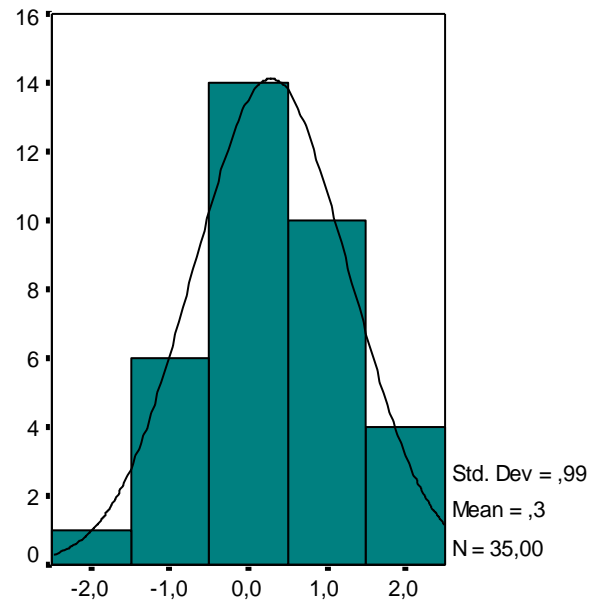

ERGNL

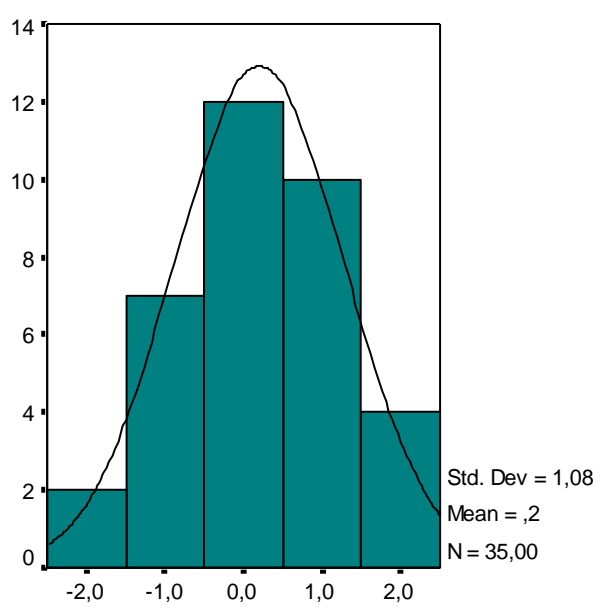

ADGNL

Figure 2. Standard deviation values of general opinion evaluation by experts of visual landscape value of Erciş and Adilcevaz Coastal areas

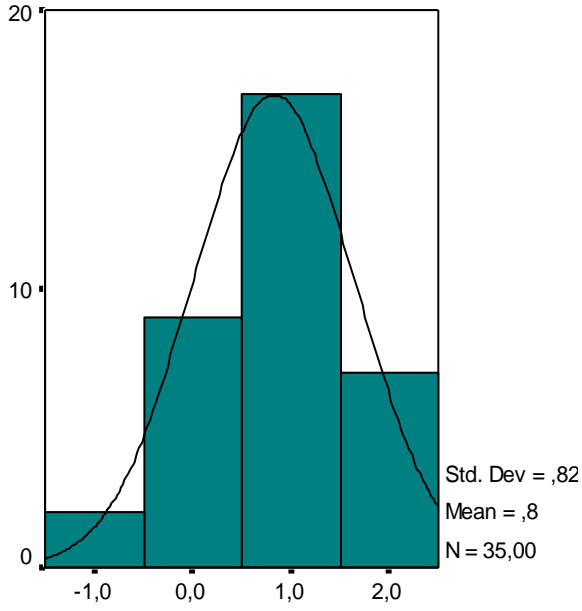

AHGNL

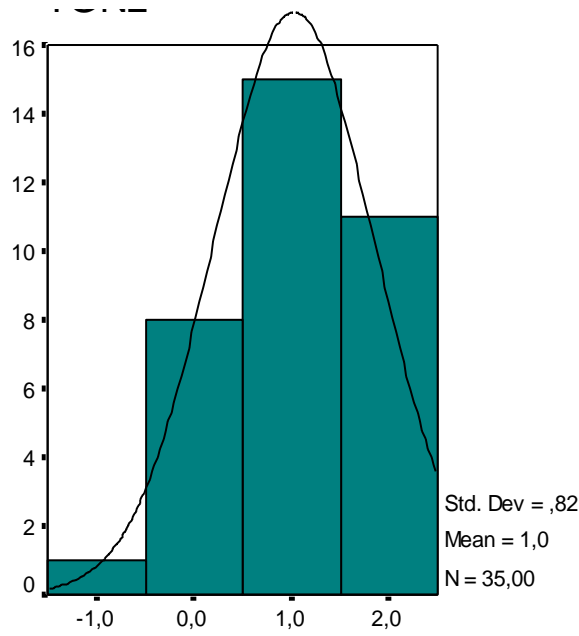

TGNL

Figure 3. Standard deviation values of general opinion evaluation by experts of visual landscape value of Ahlat and Tatvan Coastal areas 


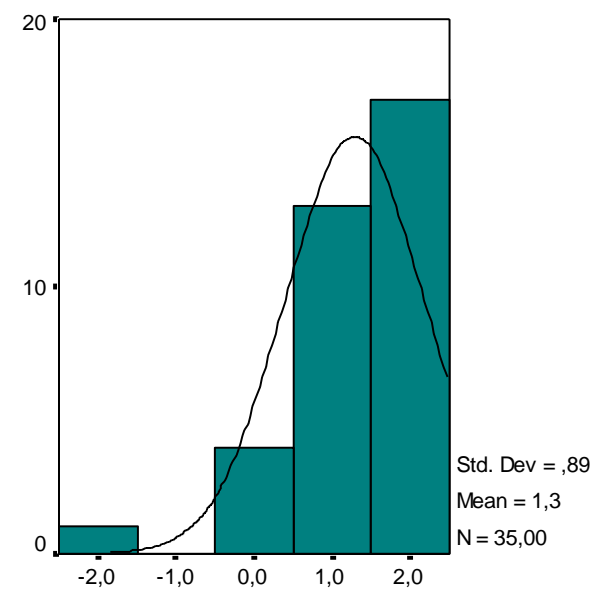

GGNL

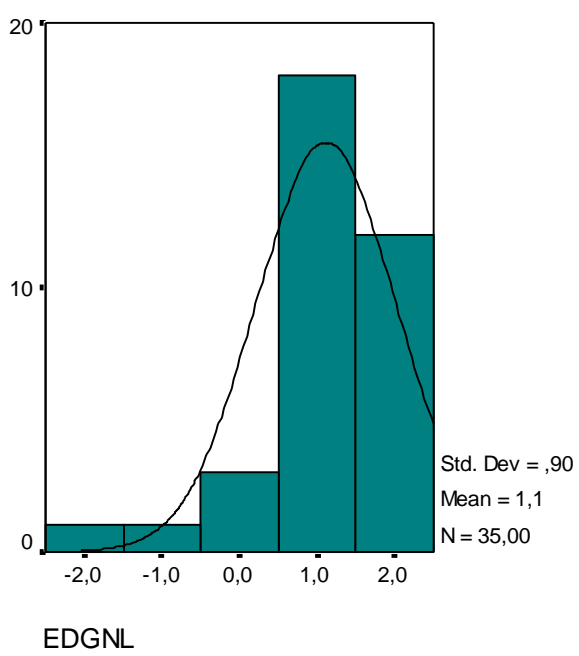

EDGNL

Figure 4. Standard deviation values of general opinion evaluation by experts of visual landscape value of Gevaş and Edremit Coastal areas

When the evaluation results of the Erciş's coastal area is investigated (the one with high level of flat topography) according to the visual landscape biophysical parameters it is found that: the lack of man-made elements contribute to the attraction of the locations in the coastal areas of the Erciş based on inspection of positive artificial structures parameter for the landscape elements. The results are in accordance with the actual vegetation levels of the districts.

Coastal area of the Erciş has received low scores in terms of protection of naturalness. In terms of water presence, the district of Erciş achieved the highest score for its waterscape beauty, as can be seen in Table 3 .

As can be observed from Table 4, Adilcevaz's coastal area received the lowest score in terms of vegetation presence, presence of human-made positive elements, and variety of colors. The results also parallel the vegetation presence of the district.

When the assessment results of the Ahlat's coastal area is analysed against the biophysical parameters of the visual Ahlat's coastal area received the lowest score in terms of vegetation presence and presence of human-made positive elements. On the other hand, as can be seen from Table 5, Ahlat's coastal area received the highest score in terms of water view.

When the assessment results of the Edermi's coastal area according to visual landscape biophysical parameters as can be observed from Table 6, the interpretation of this result indicates that positive artificial structures parameter for the landscape elements reveals the lack of man-made elements contributing to the attraction of the locations in the coastal areas of the Tatvan. While as can be seen from Table 6, Tatvan's coastal area received the highest score in terms of water view and variety of colors.

When the biophysical property of naturalness parameter is inspected, the Q-sort analysis supports the fact that Gevaş's coastal area has a lower amount of settlements. When the parameter of vegetation presence is inspected, it can be realized that although being quite small in size, the coastal area of the Gevas district were given the highest scores. This is probably due to the presence of the only forest in the region. The outcomes of the Q-sort analysis also parallel the vegetation presence of the district. In terms of water presence, the district of Gevaş achieved the highest score for its 
waterscape beauty, as can be seen in Table 7. Since this coastal area is farther than the city center compared to other locations' shorelines, it has a clearer water overall, also reflected in the results of the questionnaire.

When the assessment results of the Edermi's coastal area according to visual landscape biophysical parameters is inspected, it is found that: Edremit's coastal area received a high score in terms of water view and variety of colors. Being called the "Green Edremit" in the region, Edremit is rich in terms of vegetation presence. The results are in accordance with the actual vegetation levels of the districts (Table 8).

Towards the north and west of the Van Lake lie the volcanic mountain masses, while its southern side is dotted with high-slope mountain ranges; the east and northeast are relatively lower in terms of morphological formations. This configuration has also influenced the results of the questionnaire. When the topographical variety parameter of the study area is inspected, it can be understood that the presence of formations of various heights contributing to the vistas was reflected into the results of the questionnaire as higher scores. Results of the analysis reveal that the Gevaş coastal area received the first position in terms of morphological variation, while Edremit coasts were placed second with a close score.

These results show that the balance between natural and man-made elements was lost for all the locations. Since the region lacks the understanding of sustainable landscaping, suitable for the nature and identity of its elements, the problematic urbanization of the coastals seems inevitable. This is also reflected in the result of the questionnaire.

Displays the results for the color variation biophysical parameter where Edremit coastal landscape earns the highest score. The interpretation of this result indicates that while the coastal of Gevaş district had indeed preserved its naturalness, it is somewhat lacking in color variety, while the coastal landscaping conducted by local authorities in the Edremit district had indeed increased the color variety and attractiveness of the location. Adilcevaz coastal landscaping, on the other hand, was given the lowest score in terms of color variety.

\section{Conclusion and Suggestions}

As a result of the ongoing population increase, it becomes inevitable that humankind disturbs the nature more and more every day. Presenting a source for beautiful visual resources, coastal areas are being repurposed through landscaping so they can provide for the physical and recreational/touristic requirements of the population. When carried out improperly, such landscaping results in serious environmental problems in these coastal regions. Evaluation of these areas in terms of their visual landscaping impact enables the decision makers to determine the priority for preservation and restoration studies, offering solutions for improving and preserving modern settlement areas in terms of sustainable landscaping.

In the present study, the coastal areas of 6 significant locations commonly visited by the local population in the Van Lake Basin, namely Erciş, Adilcevaz, Ahlat, Tatvan, Gevaş, and Edremit districts, are evaluated in terms of their visual landscape qualities. These locations are very popular recreational areas for visitors, especially during summer months and weekends. Considering the fact that visual landscape quality has a strong influence on the recreational attraction, the landscaping of these locations are conducted, heeding some of the most important criteria. The outcomes of the 
evaluations revealed that the highest scores were achieved by Gevaş, Edremit, and Tatvan districts' coastal regions, respectively (Figure 5). The general view of the coastal areas, their naturalness, and the presence of vegetation were determined to be the most influential parameters.

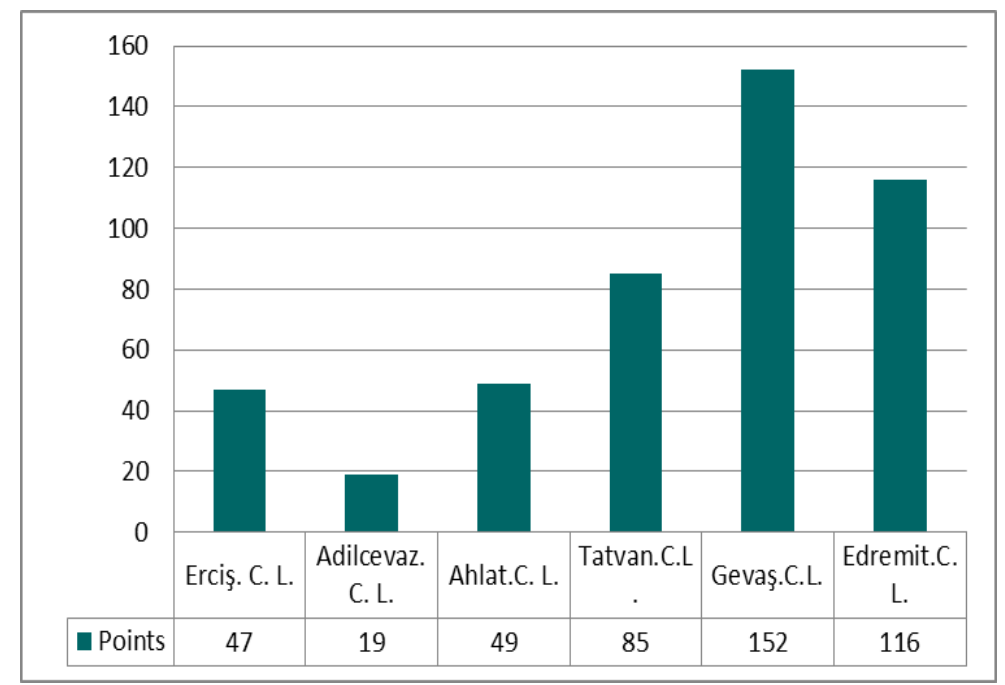

Figure 5. Results of the visual landscape quality evaluation of the coastal area

The analysis conducted in this study reveals that the highest score in terms of general attractiveness was achieved by the coastal area of the Gevaş district, followed closely by the coastal strips of Edremit district. Among all the locations under study, the Gevas coastal area maintained its naturalness to the highest level; thus, it received the best score in terms of biophysical parameters of the visual landscape. While these two locations achieved high scores due to their vegetation presence, dominating water presence and beauty, and topographical variety, they received no scores for the manmade positive landscape elements. This shows that the landscaping conducted in the region by the authorities was not approved by the experts. Similar results were also achieved for Ahlat, Erciş, Tatvan and particularly for Adilcevaz coastal areas, as the landscape designs applied in these locations are unrelated to the identities of the locations, looking like ordinary parks.

The lowest scores for the visual landscape evaluation were obtained by the coastal areas of Adilcevaz district, presenting an urgency and priority for restoration and improvement studies for the location. To achieve this, the weak vegetation presence in the coastal areas of Adilcevaz could be initially enhanced, using ample amounts of plants appropriate for the ecological conditions of the region. Meanwhile, prevention of the waste being dumped into the lake should be sufficient to improve the visual quality of the water itself. All of the coastal areas included in the study suffered from the lack of positive contribution of man-made landscape elements, receiving low scores for this particular parameter. Considering this, future artificial landscape elements should be designed considering the history of the locations. A strategy should also be employed to choose appropriate construction materials, accessories, and local plants.

The coastal areas of Gevaş and Edremit districts were highly praised by the experts in the study; thus, they can be the focus of future preservation efforts and utilization of 
sustainable landscape strategies. These strategies should be developed based on most influential biophysical parameters discussed in this study.

The coastal areas of the Van Lake are subject to the Shore Protection Law (no 3621) (Anonymous, 2018c). Implementation and execution of preservation and protection laws is essential for prevention of constructions breaching the Construction Zoning Law and the damages caused by solid and liquid wastes. Construction of facilities that aid community life by focusing on recreation, entertainment, culture, sports, and social aspects are of paramount importance, but they should also adhere to determined constructions of the selected strategy and preserve natural habitats and vistas. The landscaping studies should be reinforced by the contribution of decision makers, communities, and their engagement in consciousness-raising efforts, taking into consideration the vistas and views into the plans. Cooperation between the institutions in various scales is also necessary to properly manage the visual resources in the preservation and restoration of coastal landscape regions.

\section{REFERENCES}

[1] Anonymous. (2000): European Landscape Convention. - Council of Europe, ETS no.176, Florence, Italy.

[2] Anonymous. (2018a): Governorship of Van. - www.van.gov.tr/ (Accessed: February, 2018).

[3] Anonymous. (2018b): Governorship of Bitlis. - www.bitlis.gov.tr/ (Accessed: February, 2018).

[4] Anonymous. (2018c): Van Governorship Provincial Directorate of Environment and Urbanization (Van Valiliği Çevre ve Şehircilik İl Müdürlüğü). https://www.van.csb.gov.tr/vangolu-kiyi-kenar-cizgisi-çalişmalari- tamamlandi-haber. (Accessed: Agust, 2018) (in Turkish).

[5] Arriaza, M., Ortega, J. F. C., Medueno, J. A. C., Aviles, P. R. (2004): Assesing The Visula Quality of Rural Landscapes. - Landscape And Urban Planning 69: 115-125.

[6] Aşur, F. (2017): Van Kenti Yakın Çevresi Kıyı Alanı Örneğinde Sulak Alanlar ve Görsel Peyzaj Kalite Değerlendirmesi. - Türk Tarım ve Doğa Bilimleri Dergisi 4(4): 506-515. (in Turkish).

[7] Ayad, Y. M. (2005): Remote Sensing And Gis In Modeling Visual Landscape Change: A Case Study of The Northwestern Arid Coast of Egypt. - Landsc. Urban Plan. 73: 307-325.

[8] BCMF. (British Colombia Ministry of Forests). (1997): Visual Landseape Inventory: Proeedures And Standards Manual. - B.C. Ministry of Forests, Forest Praetiees Branch For The Culture Task Force, Resourees Inventory Committee.

[9] Bitlis Provincial Directorate of Culture and Turism (Bitlis Il Kültür ve Turizm Müdürlügü 2018): connection on 20 December 2018. - http//:www.bitliskulturturism.gov.tr.

[10] BLM. (2016): Visual Resourse Management System. - U.S. Department of The Interior Bureau of Land Management Website: http://www.blmwyomingvisual.anl.gov/docs/blm_vcr.html. (Accessed: April 2017).

[11] Bozhüyük, Z. (2007): Visual Impact Assessment of Some Historical Buildings and Environment in Erzurum City Centre. - Erzurum: Atatürk University Graduate School of Natural and Applied Sciences Department of Landscape Architecture.

[12] Bulut, Z., Y1lmaz, H. (2007): Determination of landscape beauties through visual quality assessment method: A case study for Kemaliye (Erzincan/Turkey). - Environmental Monitoring and Assessment 141 (1-3): 121-129.

[13] Burmil, S., Daniel, T. C., Hetherington, J. D. (1999): Human values and perceptions of water in arid landscapes. - Landscape and Urban Planning 44: 99-109.

[14] Clark, J. R. (1996): Coastal Zone Management Handbook. - CRC Press, Inc. 
[15] Clay, G. R., Daniel T. C. (2000): Scenic Landscape Assesssment: The Effects of Land Management Jurisdiction on Public Perception of Scenic Beauty. - Landscape And Urban Planning 49: 1-13.

[16] Clay, G. R., Smidt, R. K. (2004): Assessing The Validity And Reliability of Descriptor Variables Used In Scenic Highway Analysis. - Landscape And Urban Planning 66: 239255.

[17] Coşkun, Ç., Kaplan, A. (2001): Urla (İzmir) Kent Merkezi ve Yakın Çevresi Örneğinde Görsel Etki Değerlendirmesi Çalışması. - Ege Üniversitesi Araştırma Projesi-ZRF-36, İzmir. (in Turkish).

[18] Çakcı, I. (2007): Peyzaj Planlama Çalışmalarında Görsel Peyzaj Değerlendirmesine Yönelik Bir Yöntem Araştırması. - Ankara Üniversitesi, Fen Bilimleri Enstitüsü, Peyzaj Mimarlığı Anabilim Dalı, Ankara, 109 s. (in Turkish).

[19] Daniel, T. C. (2001): Whither scenic beauty? Visual landscape quality assessment in the 21st century. - Landscape and Urban Planning 54: 267-281.

[20] Daniel, T. C., Boster, R. S. (1976): Measuring Landscape Esthetics: The Scenic Beauty Estimation Method. - USDA Forest Service Research Paper, RM-167. Rocky Mountain Forest and Range Experiment Station, Fort Collins, CO.

[21] Dupont, L., Ooms, K., Duchowski, A. T., Antrop, M., Van Eetvelde, V. (2017): Investigating the visual exploration of the rural-urban gradient using eye-tracking. Spatial Cognition \& Computation 17(1-2): 65-88.

[22] Duru, B. (2001): Kıyı Yönetiminde Bütüncül Yaklaşımlar ve Ulusal Kıyı Politikası. Basılmamış Doktora Tezi. Ankara Üniversitesi, Sosyal Bilimler Enstitüsü, Kent ve Çevre Bilimleri ABD, Ankara. (in Turkish).

[23] Golchin, P., Narouie, B., Masnavi, M. R. (2012): Evaluating visual quality of educational campus based on users preferences. Case study: Sistan and Baloochestan University, Iran. - Journal of Environmental Studies 38(62): 43.

[24] Gruehn, D., Roth, M. (2008): New Approaches in visual landscape assessment and modelling. - In Quality of Life and Aesthetic Value of Landscape. International Landscape Architecture Conference Proceedings. Latvia University of Agriculture, Jelgava, Latvia (p. 6).

[25] Gülez, S., Kaya, L. G., Dönmez, Ş., Çetinkale, S., Koçan, N. (2007): Mugada Kıyı Alanı Peyzaj Düzenlemesi Üzerine Bir Çalışma. - ZKÜ Orman Fakültesi Dergisi 9: 12. (in Turkish).

[26] Hall, F. C. (2001): Ground-Based Photograph Monitoring. - United States Department Of Agriculture, Forest Service, Pacific Northwest Research Station, General Technical Report, Pnw-Gtr-503.

[27] Hepcan, C. (2003): The Study in the context of visual impact assessment of Urla (İzmir) town center and its environs. - İzmir: Ege University, Institute of Science and Landscape Architecture Department, M.Sc.

[28] Huang, J. (2014): Landscape Visual Quality Assessment in Washtenaw County. - School of Natural Resources And Environment University of Michigan, A. Ar. 18-1.

[29] Jahany, A., Makhdoom, M., Feghhi, J., Etemat, V. (2012): Determine the Quality of the Landscape and the Outlook in Order to Ecotourism; Case Study: Patom Forest Kheiroud. - Environmental Studies 2(3): 13-20. (in Persian).

[30] Kane, P. S. (1981): Assessing landscape attractiveness: A comparative test of two new methods. - Applied Geography 1(2): 77-96.

[31] Kaptanoğlu, Ç. A. Y. (2006): Peyzaj Değerlendirmesinde Görsel Canlandırma Tekniklerinin Kullanıcı Tercihine Etkileri. - İstanbul Üniversitesi, Orman Fakültesi, Fen Bilimleri Enstitüsü, Peyzaj Mimarlığı Anabilim Dalı, Doktora Tezi, İstanbul, 203 s. (in Turkish).

[32] Karabey, H. (1978): Kıyı Mekânının Tanımı, Ülkesel Kıyı Mekanının Düzenlenmesi İçin Bir Yöntem Önerisi. - O.D.T.V, Mimarlık Fakültesi Dergisi Cilt 4, Sayı 1.S: 92-116. (in Turkish). 
[33] Kaya, L. G. (2006): Critical Barriers to Rational Planning Processes for Coastal Zone Management: The Case Study of Antalya, Turkey. - Ph.D. Dissertation. State University of New York, College of Environmental Science and Forestry, Faculty of Environmental Studies.

[34] Keleş, E., Atik, D., Bayrak, G. (2018): Visual Landscape Quality Assessment in Historical Cultural Landscape Areas. - European Journal of Sustainable Development 7(3): 287-300.

[35] Kramer, B., Hegedus, P., Gravina, V. (2003): Evaluating a Dairy Herd Improvement Project in Uruguay to Test and Explain Q Methodology. - Proceedings of the 19th Annual Conference Raleigh, North Carolina, USA.

[36] Lothian, A. (1999): Landscape and the philosophy of aesthetics: Is landscape quality inherent in the landscape or in the eye of the beholder? - Landscape and Urban Planning 44: 177-198.

[37] Naspetti, S., Mandolesi, S., Zanoli, R. (2016): Using visual Q sorting to determine the impact of photovoltaic applications on the landscape. - Land Use Policy 57: 564-573.

[38] Özhanc1, E., Yılmaz, H. (2011): Rekreasyon alanlarının görsel peyzaj kalitesi yönünden değerlendirilmesi; Erzurum Örneği. - Iğdır Üniversitesi Fen Bilimleri Enstitüsü Dergisi 1(2): 67-7. (in Turkish).

[39] Palmer, J. F., Hoffman, R. E. (2001): Rating reliability and representation validity in scenic landscape assessments. - Landscape and Urban Planning 54(1-4): 149-161.

[40] Palmer, J. F. (2003): Research Agenda for Landscape Perception. - In: Buhmann, E., Ervin, S. Trends in Landscape Modeling. Heidelberg: Wichmann Verlag (pp. 163-172).

[41] Palmer, J. F. (2019): The contribution of key observation point evaluation to a scientifically rigorous approach to visual impact assessment. - Landscape and Urban Planning 183: 100-110.

[42] Parsons, R., Daniel, T. C. (2002): Good looking: in defense of scenic landscape aesthetics. - Landscape Urban Plan. 60: 43-56.

[43] Sevenant, M., Antrop, M. (2009): Cognitive Attributes and Aesthetic Preferences in Assessment and Differentiation of Landscapes. - Journal of Environmental Management 90(9): 2889-2899.

[44] Smardon, R. C. (1979): Prototype Visual Impact Assessment Manual. - School of Landscape Architecture, University of New York.

[45] SNH. Scottish Natural Heritage. (2013): A Handbooko Environmental Impact Assessment. - Guidance for Competent Authorities, Consultees and Others Involved in the Environmental Impact Assessment Process in Scotland.

[46] Soykan, F. (2000): Kirsal Turizm ve Avrupa'da Kazanılan Deneyim. - Anatolia Turizm Araştırmaları Dergisi, 11 (March-June): 21-33. (in Turkish).

[47] Uzun, O., Müderrisoğlu, H. (2011): Visual Landscape Quality in Landscape Planning: Examples of Kars And Ardahan Cities in Turkey. - African Journal of Agricultural.

[48] Van Provincial Directorate of Culture And Tourism (Van Il Kültür ve Turizm Müdürlügü 2018): connection on 20 December 2018. - http://www.vankulturturizm.gov.tr.

[49] Wherrett, J. R. (1996): Visualization Techniques For Landseape Evaluation: Literature Review. - The Macaulay Land Use Research Institute (Mlur1), Aberdeen Scotland. www.macaulay.ac.Uk/Visualisationlitrev/Chapters.html.

[50] Wu, Y., Bishop, I., Hossain, H., Sposito, V. (2006): Using GIS in Landscape Visual Quality Assessment. - Applied Gis 2(3): 18.1-18.20. DOI: 10.2104/Ag 060018.

[51] Yazici, K. (2018): Evaluation of Visual Landscape Quality In The Wetlands North Of Sivas (Turkey). - Applied Ecology And Environmental Research 16(4): 4183-4197.

[52] Yazıcı K., Aşur F., " Evaluation of The Recreational Potential of Kaz Lake (Tokat, Turkey) and According to Gulez Method And Development of Land Use Proposals ", 8th International Conference of Ecosystems , Tiran, Albania, 22-25 June 2018, Pp.172-180.

[53] Yilmaz, R. (2006): Saroz Körfezi'nin Turizm Ve Rekreasyonel Kullanim Potansiyeli Üzerine Bir Araştirma (in Turkish). - Turkish Journal of Forestry 1: 124-135. 